\title{
User Research Method for Service Design: From Conceptual Knowledge To Design Knowledge
}

\author{
Jaewoo Joo ${ }^{1}$, Dongwoo Oh$^{2}$ \\ ${ }^{1}$ College of Business Administration, Kookmin University, Seoul, 136-702, Korea \\ ${ }^{2}$ Institute of Design, Illinois Institute of Technology, Chicago, IL 60654
}

\begin{abstract}
Objective: We propose empathy as a user research method for service design. Background: We argue that empathy will enable user researchers to go beyond the conceptual knowledge to the design knowledge of user experience. Method: We tested our hypothesis by conducting an experiment in which subjects were required to propose solutions to improve the experience of a family member of a patient hospitalized in an emergency department. Results: We found that the subjects who empathized with the family member of a patient tended to suggest the solutions based on design knowledge rather than the solutions based on conceptual knowledge compared to the subjects who did not empathize. Conclusion: Data support our hypothesis that empathy enables people to focus on design knowledge rather than conceptual knowledge. Application: These findings provide practical implications for user researchers in service design.
\end{abstract}

Keywords: Service design, User research, Empathy, Conceptual knowledge, Design knowledge, Emergency department

\section{Introduction}

Cambridge University와 IBM의 공동연구소 IfM and $\operatorname{IBM}(2008)$ 는 서비스디자인(Service design)을 "The application of design methods and tools to the creation of new service systems and service activities with special emphasis on perceptions of quality, satisfaction and experience"로 정의하며, 서비스디자인 연구의 핵심은 서비 스 지식정보의 시각화에 앞서 서비스에 대한 사용자 경험분 석에 초점이 맞추어지며, 총체적 관점으로 바라본 다양한 환 경에서 발생하는 서비스 접점(Service interface) 의 발견 또 는 개선에 있다(Sangiorgi, 2009).

서비스디자인 연구는 인터랙션 디자인 또는 사회과학, 공 학 영역과 비교하여 상대적으로 학술적 연구의 초기단계이며 사용되는 방법론들은 다양한 영역으로부터 파생되었다. 서비 스디자인의 대표적인 프로세스 기반 방법론인 서비스 블루
프린트(Service blueprint)는 서비스 매니지먼트(Service management) 영역으로부터 시작되었으며(Shostack, 1984), 사용자 케이스(User case)나 행위모델(Activity diagram) 은 소프트웨어 엔지니어링 (Software engineering) 영역에 서 개발되었다(Patricio et al., 2008). 현재 활용되고 있는 서비스디자인 방법론들은 학술적 지식기반의 접근보다는 사 례중심 개발을 통한 경험적 지식기반의 이해를 바탕으로 학 습되어 오고 있다. 이러한 경험적 접근방법은 서비스디자인 문제해결에 있어 서비스디자이너 개인의 역량에 따라 오용 되는 문제를 야기한다. 따라서, 서비스디자인 방법론 적용 시 예상되는 오류를 줄이기 위한 학술적 지식기반의 접근이 필요하다. 또한, 다양한 영역에서 발전되어온 서비스디자인 연구기법들은 고유 목적에 적합한 양식을 지닌 까닭에 서비 스디자인 연구를 위한 창의적 서비스디자인 방법론의 개발 이 요구된다.

Corresponding Author: Dongwoo Oh. Institute of Design, Illinois Institute of Technology. 350 N. La Salle St. Chicago, IL 60654.

Mobile: 011-758-5989, E-mail: dongwoo@id.iit.edu

Copyright@2012 by Ergonomics Society of Korea(pISSN:1229-1684 eISSN:2093-8462). All right reserved. 


\subsection{New perspectives on service in research}

서비스에 관한 연구는 1940년대 서비스 분야의 등장 이 후, 1960년대 서비스업과 제조업에 관한 연구, 1970년대 소 비자를 연구대상으로 그 영역을 확장시켰다. 이러한 서비스 연구활동은 1980년대 들어서 서비스 조직 또는 서비스 매 니지먼트, 서비스 퀼리티에 관한 연구로 그 범위가 발전되었 다(Cook et al., 1999). 이후, 21세기 ICT(Information and Communication Technology) 산업 환경의 영향으로 전통 적인 서비스 산업의 대표적 특징인 무형성(Intangibility), 노동집약성(Labor intensiveness), 협업성 (Co-production) 이 약화되고 보다 복잡한 사회-기술-경제시스템(Sociotechnical-economic system)으로서의 서비스 연구가 등장 하였다(Sako et al., 2006; Chesbrough and Spoher, 2006).

ICT 산업 환경에서의 서비스디자인은, 비즈니스 관점에서 의 개념적 시스템 모델링과, 실제 서비스 구현을 위한 시스 템 모델링으로 구분된다(Gehlert et al., 2004). 이에 따라, 서비스디자인의 지식정보(Knowledge)가 비즈니스 관점의 개념적 지식정보(Conceptual knowledge) 와 서비스 구체화 와 관련된 디자인 지식정보(Design knowledge)로 구분될 수 있다.

두 지식정보의 구분은 서비스디자인을 위한 사용자 조 사 과정에서 불필요한 복잡성을 방지하고 서비스를 실제화 하는 데에 도움을 준다. 그러나, 지식정보의 내재적 특성 (Properties) 차이로 인해, 개념적 지식정보와 디자인 지식 정보의 $1: 1$ 매칭 또는 전환이 어려워, 성격이 다른 두 가지 지식정보의 흐름(Knowledge flow)이 존재하게 된다. 따라 서 지식정보를 활용하는 활동이 개념적 활동(Conceptual activity) 과 디자인 활동(Design activity)으로 나뉠 수 밖에 없고, 각 활동에 맞는 다른 정보관리 (Managing information sources) 가 필요하다고 알려져 있다(Gehlert et al., 2004; Hempe, 2011).

\subsection{Empathy as service design method}

서비스디자인 과정 중, 초기단계에서 실행되는 사용자 조 사의 전제는 사용자 니즈를 정확히 파악하면 완벽한 서비스 의 개발이 가능하다는 믿음에 있다. 사용자 니즈의 파악을 위해 사용자 조사자는 페르소나(Persona), 사용자 행태 지도 (User journey map), 서비스 블루프린트(Service blueprint), 사용자 시나리오(User scenario), 스토리보드(Storyboard) 등의 다양한 서비스디자인 방법론을 사용한다. 그러나, 이러 한 방법론들을 부적절하게 사용함으로서 사용자 니즈에 대한 정확한 이해라는 기대와는 달리 정형화된(Stereotypical) 사 용자 니즈가 발견되는 사례들을 어렵지 않게 발견할 수 있다.
이러한 현상에 대해, 디자인 영역과 비즈니스 영역에서 활 동하는 일부 학자들은, 다수의 사용자들이 정형화된 사용자 니즈를 가지고 있으니 이를 바탕으로 서비스/제품을 개발하 는 것이 문제가 되지 않는다고 주장한다. 예를 들어, Griffin and Hauser(1993)는 마케팅 학계에 품질의 집(House of Quality) 과 고객의 소리(Voice of Customer)라는 용어를 소개하면서, 약 25 명의 소비자 조사만으로 전체 소비자 니 즈의 $90 \%$ 를 발견할 수 있음을 실험을 통해 증명했다. 이를 통해, 소비자 니즈는 상당부분 정형화되어 있으며, 많은 소 비자들을 일일이 찾아서 인터뷰할 필요가 없음을 주장하였 다. Turner, P. and Turner, S. (2011)는 이에서 더 나아가, 제품디자인 개발에 있어서 사용자 니즈는 내재적 특성으로 인해 정형화될 수 밖에 없다고 주장하며 새로운 사용자 니즈 를 발견하지 않는 사용자 조사를 옹호했다.

그러나, 정형화된 사용자 니즈를 발견했다는 사실이 사용 자 조사 데이터 즉, 사용자 조사 결과로 얻어지는 지식정보 (Knowledge) 가 정확하다는 것을 의미하지는 않는다. 사용 자 니즈의 정확성이 서비스디자인에서 중요한 요소임에도 불구하고 특정한 사용자 니즈를 발견하지 못하는 것은, 사용 자 조사의 전제 조건인 사용자 니즈에 대한 정확한 이해에 부합되지 않는다.

본 연구에서는 서비스디자인을 위한 사용자 조사방법으로 서 공감 기법을 제시한다. 이론적 접근과 실험을 통해 1) 사 용자 조사를 통해 정형화된 사용자 니즈가 발견되고 특정한 사용자 니즈가 발견되지 않는지 문제점을 이론적으로 설명 하고, 앞서 밝힌 2) 개념적 지식정보와 디자인 지식정보의 존재를 확인함으로써 서비스디자인을 위한 사용자 조사방법 으로 공감 기법의 효용성을 논의한다.

\section{Literature Review}

이론적 배경은 세 개의 장으로 구성되어 있다. 첫 번째 장 에서는, 사용자 조사 과정에서 사용자가 자신의 경험을 충분 히 설명하지 못하는 현상을, 심리학의 의사결정 연구를 통해 설명한다. 두 번째 장에서는, 사용자 조사 과정에서 조사자 가 사용자의 경험을 충분히 설명하지 못하는 현상을, 심리학 의 귀인 연구를 통해 설명한다. 마지막으로 세 번째 장에서 는, 심리학의 공감 연구에 기반하여, 이러한 문제를 극복할 수 있음을 주장한다.

\subsection{Psychology of decision making}

심리학의 의사결정 연구에 따르면, 사람은 판단과 의사결 
정을 할 때 휴리스틱이라는 심리적 지름길을 이용하는 경우 가 종종 있으며, 이를 통해 가용한 최상의 결론에 빨리 도달 할 수 있다는 특징이 있다. 하지만 휴리스틱을 이용한 의사 결정은 편견을 불러올 수 있다는 단점이 있다.

특히 "여러 행동으로 구성된 하나의 순차적 경험"을 설명 할 때, 휴리스틱을 이용하면 실제 경험과 설명된 경험 간에 차이가 존재할 수 있다는 연구 결과들이 많다. 순차적 경험을 설명할 때, 이와 관련된 기존 지식에 의존함으로서 실제 경 험에서 행하지 않은 행동을 설명하거나 실제 경험에서 행한 행동을 설명하지 않는 경우들이 있으며(Smith and Houston, 1985). 또는, 실제 경험에서 인상이 깊은 행동과 마지막 행 동을 포함한 몇 개의 핵심 행동만을 이용하여 설명하는 경 우가 있다(Kahneman, 1999; Kruger and Evans, 2004). 즉, 사람들은 실제 경험보다 경험을 압축하여 간단하게 설명 하는 경향이 있다.

\subsection{Psychology of attribution}

심리학의 귀인 연구에 따르면, 사람은 타인의 경험을 정확 하게 설명할 수 없으며, 타인이 행한 행동의 원인이나 결과 를 옳지 않게 추론하여 틀린 결론에 도달하는 경향이 있다.

사람들은 자신의 행동의 원인이 상황에 있다고 생각한다. 하지만 타인의 행동을 관찰하고 설명할 때에는, 타인에 대한 정보가 부족하기 때문에, 타인의 행동의 원인이 타인의 소인 이라고 추론하는 경향이 있다(Gilbert and Malone, 1995). 이러한 연구 결과는 많은 연구 자들에게 영향을 끼쳐, 이후 본인-타인 간 귀인의 차이를 줄이기 위한 많은 노력들이 있 었으나, 대부분 귀인 차이를 극복하지 못했다(Gilbert and Jones, 1986).

\subsection{Psychology of empathy}

심리학의 공감에 관한 연구에 따르면, 본인-타인 간 귀인 의 차이를 효과적으로 줄일 수 있는 방법으로 관점 바꾸기가 제시된다. 즉, 본인이 자신의 행동을 설명할 때, 타인의 입장 에서 자신의 행동을 설명하면, 자신의 소인에 귀인하는 경향 이 증가한다(Storms, 1973). 이와 반대로, 타인이 타인의 행동을 설명할 때, 본인의 입장에서 타인의 행동을 설명하 면, 상황에 귀인하는 경향이 증가한다(Regan and Totten, 1975).

최근의 공감 연구는 과거에 일어난 타인의 행동의 원인 을 이해하는 것에서 한발 더 나아가, 현재 타인의 심리나 미래 타인의 행동을 예측하는 기법으로서 공감이 제시된다. Galinsky and Moskowitz(2000)에 따르면, 관점 바꾸기는 사회적 통념에 기반한 편견을 회피할 수 있는 기법으로 제시
된다. 노인에 관한 실험을 통해, 관점 바꾸기가 사회적 편견 을 줄여서 노인 개개인에 대한 이해도를 증가시킨다는 것을 실험으로 보여주었다.

\subsection{Conclusion and hypotheses}

위와 같은 이론적 배경을 통해, 사용자 조사자는 사용자의 니즈를 정확히 설명하지 못한다고 결론을 내린다. 이러한 문 제점을 해결하기 위해 공감 기법을 제안하며, 이를 통해 사 용자 조사자가 사용자의 상황과 행동을 이해함으로써, 정형 화되지 않은 사용자 니즈를 찾아낼 수 있을 것이라고 가정 한다. 즉, 사용자 조사자가 공감 기법을 사용하면, 사용자가 격는 경험과는 관련이 적은 일반적이고 구조적인 정보에서 벗어나, 사용자가 격는 경험과 관련이 많은 개인적이고 특수 한 정보를 더욱 많이 획득할 수 있을 것이라고 가정한다.

가설1. 공감 기법을 사용하지 않은 사람은, 공감 기법을 사 용한 사람에 비해, 경험에 대한 구조적 형태의 개념 적 지식정보(Structured conceptual knowledge) 를 더욱 많이 설명할 것이다.

가설2. 공감 기법을 사용한 사람은, 공감 기법을 사용하지 않은 사람에 비해, 경험에 대한 순차적 형태의 디자 인 지식정보(Procedural design knowledge)를 더 욱 많이 설명할 것이다.

\section{Experiment}

\subsection{Procedure}

가설을 증명하기 위하여 하나의 실험을 행하였다. 본 실험 은 피험자 간 설계(2 between-subjects design)로 구성되 었다. 따라서, 한 그룹은 공감 기법을 사용한 실험 그룹이며, 다른 한 그룹은 공감 기법을 사용하지 않은 대조 그룹으로 구성되었다. 두 그룹에게는 동일한 형태를 가진, "여러 행동 으로 구성된 하나의 순차적 경험"이 글로 제공되었으며, 모 든 피험자들은 이를 바탕으로 사용자의 경험을 개선하는 일 을 수행하였다. 수집된 개선점을 통하여, 두 그룹 간 사용자 경험을 이해하고 개선하는 방식에 근본적인 차이가 있는지 살펴보았다.

공감 기법은 기존 연구에 근거하여 다음 문장을 읽도록 한다(Davis et al., 1996).

"When you read the required tasks in an emergency department, please imagine how you yourself would experience if you were a family member of a patient. In 
your mind's eye, trade places with him or her and imagine as if the events were actually happening to your family."

\subsection{Stimulus}

"여러 행동으로 구성된 하나의 순차적 경험"으로는 응급실 (Emergency Department)에 실려온 환자의 가족이 처리해 야만 하는 행동들을 선택하였다. 응급실에서의 환자 가족의 경험은 다음 두 가지 이유로 선택되었다. 첫째, 응급실에서 취하는 일련의 행동들은 하나라도 빠뜨리거나 중간에 그만 둘 수 없는 강제적으로 취해야 하는 순차적 경험이다. 따라 서 모든 피험자들이 같은 경험을 접하게 된다. 둘째, 모든 피 험자들이 환자 가족이 취해야 하는 동일한 행동들을 읽고 그 들의 경험을 개선하도록 동일하게 요구받았기에, 다른 이유 로 그들의 경험이 개선될 수 있다는 대안 가설을 차단하는 효과가 있다.

피험자들에게는, Southwest Memorial Hospital의 Emergency Service에서 제공하는, 응급실 환자의 가족이 취해야 하는 8 단계의 순차적 행동들이 제공되었다.

1. Triage: Every patient seen in the emergency department begins with an evaluation by a nurse, through a process called "triage." The nurse examines the patient to determine which division of the emergency department will see the patient.

2. Registration: Family members register the patient at the outpatient admission desk.

3. Doctor's examination: Family members will be shown to an exam room, where the patient is examined and treated by a doctor, nurse or EMT in order of emergent priority only.

4. X-Rays: If the patient needs to have $\mathrm{X}$-rays taken, she is taken to the X-ray department by cart, wheelchair or walk and has taken $\mathrm{X}$-rays.

5. Laboratories: If the patient needs lab work done, the nurse, EMT or lab technician takes the necessary blood and/or urine sample and sends it to the lab.

6. Pharmacy: Family members go to the hospital pharmacy for her medicine.

7. Admission: The patient will be transferred to a patient room or if needed transferred to a facility for specialty care.

8. Billing: Family members receive one bill for hospital and nursing charges and one bill from the physician who supervises the visit. Family members provide the hospital with information about their insurance.

\subsection{Measurements}

공감 기법이 효과가 있는지 측정하기 위하여, 두 그룹에게 다음 두 개를 공통으로 질문하고, 7점 척도로 응답을 요구 한 뒤, 두 그룹간 차이가 있는지 확인했다 ((a) "To what extent did you try to imagine how you yourself would experience if you were experiencing what happened to the family member of a patient in an Emergency Department?" (b) "To what extent did you actually imagine how you yourself would experience if you were experiencing what happened to the family member of a patient in an Emergency Department?").

두 그룹은, 응급실 환자의 가족이 겪는 경험에 얼마나 많 은 문제점이 있는지 문제점을 개수로 제시하도록 요구받았 고, 제시한 문제들을 개선하여 경험을 개선하는 해결책을 개 수로 제시하도록 요구받았으며, 마지막으로 하나의 핵심 해 결책을 제시하도록 요구받았다. 문제점과 해결책의 개수와 종류를 분석하여, 두 그룹간 사용자 경험에 대한 이해도를 수치로 비교했으며, 사용자 경험을 개선하는 핵심 해결책의 종류도 함께 비교했다.

\subsection{Findings}

토론토 대학의 경영대학에 재학중인 33명의 대학 학부생 들이 실험에 참가했다.

먼저, 간단한 문장읽기가 공감을 성공적으로 불러일으킨다 는 점을 두 개의 질문을 통해 확인했다. 문장을 읽은 그룹은 응급실 환자의 가족의 입장을 더 많이 받아들이려고 노력했 으며 $($ 공감 그룹 $=3.95 \mathrm{vs.} \mathrm{비공감} \mathrm{그룹}=2.5, \mathrm{t}(31)=2.73$, $p<.01)$, 또한 그들의 입장을 실제로 더 받아들였다고 응 답했다 $($ 공감 그룹 $=3.53$ vs. 비공감 그룹 $=2.14$, t $(31)=$ $2.61, p<.05)$.

다음으로, 공감 그룹은 비공감 그룹에 비해서, (a) 응급실 환자의 가족이 겪는 경험에 더 많은 문제가 있다고 기술했으 며 (공감 그룹 $=3.53 \mathrm{vs.} \mathrm{비공감} \mathrm{그룹}=2.21, \mathrm{t}(31)=2.13$, $p<.10)$, (b) 응급실 환자의 가족이 겪는 경험을 개선하는 더 많은 해결책을 제시했다(공감 그룹 $=4.32$ vs. 비공감 그룹 $=2.50, \mathrm{t}(31)=1.70, p<.15)$.

무엇보다도, 두 그룹이 제시하는 핵심 해결책의 종류가 달 랐음을 확인할 수 있었다(Table 1 참조). 먼저, 비공감 그룹 의 실험 참가자들은 의료 시스템이나 응급실 운영에 관한 구 조적인 문제점들에 초점을 맞추어, 이를 해결하는 것이 응급 실 환자의 가족에 더 나은 경험을 줄 수 있다고 주장하는 경 
Table 1. Key solutions proposed by participants

$$
\text { NO empathy group }
$$

It is very important to hire a competent staff who can react well under pressure.

Get more medical school students come and follow by some doctors in the hospital, enable them to work at hospital as soon as possible after graduate

The reception should arrange appointment more efficiently and they should always prepare some extra resource(ie. doctors, chairs) in case there are too many patients.

I believe the process seemed fine and reasonable when reading it over however, I do believe that some respect and compassion is needed and that billing should not be the last step the family experiences at the hospital.

In order to reduce the risk of making judgmental mistakes, the hospital can assign a doctor to examine a patient in a triage step to decide what kind of care he/she needs.

Make sure there are funds lined up for a situation in which something terrible can occur.

Hospitals need to cut bureaucratic red tape and hire more doctors to solve this problem.

Allow doctors to see patients right away instead of letting nurses examine them. And allow family members to be with patients with they are being asked questions about their health problems.

The best answer is for the family to get the appropriate identification for the loved one by calling someone to pick up the id or go down themselves to properly register the patient and to relax and remain calm at all times in order to help the patient!

Put the damaged part into cold water or ice...

Because the patient is being treated, it is only normal that family members feel anxious, upset, and scared. In order to improve their mental/ emotional status, the hospital should be willing and able to assign a member of the hospital

Also add other corporate chains in the hospital.

Hospitals should have more medical staff in hospitals which allows for a shorting wait time for emergency patients, as they would not go to the hospital if they do not feel that it is an emergency.

\section{Empathy group}

If a person is in a state of emergency, it is best to reassure the family members and report the status of the patient situation. They should also tell them what they should do, ie. call family members. Make sure there is a support group for the waiting

We shouldn't say anything serious matter to family members directly.

To cut some of the process before seeing the doctor

They should try to shorten the process of each process and reduce the steps that are not necessary in ER, because it is very critical for the patients and their family. Also they should let the family know before they proceed the next step

Ensure efficiency and availability and meet the needs of each customer.

The best solution would be to approach problem with calm and rational manner if possible.

I think the most important is to control the mood of family members and definitely not let these family members affect other people in the hospital as well.

Hiring competent and efficient employees who are capable of using machines, managing time to ensure the most patients can be seen to, who can remain calm under stressful situations and are emotionally intelligent to tend to family members.

Find another hospital, if there's a line up

I think that the best solution is the training sessions to be held regularly for all medical staff.

When a family member is sent the emergency room, there must be some serious illness for that person to go there. The family member would hope that they don't have to wait in line to get treated and hope that the family member would be ok.

To raise the professional image of nurse would allow family members of the patients as well as the patient not to worry, once they come to the EMG, they always think they are serious, so they need a professional nurse to evaluate them.

I think the hospital should just always be friendly, don't leave the patients waiting, offer many solutions for the rest of the family or person with particular patient and find solutions and give the family options to eliminate any chance of complaints

If the patient does not have an immediate family member present, the nurse should get his/her OHIP card to bring up the patient's medical record. Next, the family members should be contacted in case the patient is unable to make an informed decision.

The best solution would be to better prioritize patients. In this case, the problem would be that the woman needs treatment immediately, but her priority is less important than other patients.

Need to hire more staff, both administrative and medical - have a better organization, keep waiting patients constantly informed of their status 
우가 많았다. 예를 들어, 병원은 최악의 상황을 대비한 자금 을 확보해야 한다거나(make sure there are funds lined up for a situation in which something terrible can occur), 관료적인 형식주의를 없애고 더 많은 의사를 고용해야 한다 거나(hospitals need to cut bureaucratic red tape and hire more doctors to solve this problem), 학교를 통해 더 많 은 의료인력을 고용해야 한다거나(get more medical school students come and follow by some doctors in the hospital, enable them to work at hospital as soon as possible after graduate), 더 나은 의료인력을 고용해야 한다거나(It is very important to hire competent staff who can react well under pressure), 또는 간호사를 대신하여 첫 단계부 터 의사가 직접 검사와 진찰을 해야 한다거나(in order to reduce the risk of making judgmental mistakes, the hospital can assign a doctor to examine a patient in a triage step to decide what kind of care he/she needs), 안내 데스크가 환자들을 효과적으로 관리해야 한다는 주장 이 제기되었다(the reception should arrange appointment more efficiently and they should always prepare some extra resource (i.e. doctors, chairs) in case there are too many patients).

이에 반하여, 공감 그룹은 응급실 환자의 가족이 겪는 경 험 자체가 가진 근본적인 문제점을 거론하고 이를 개선하려 는 경향이 많았다. 예를 들어, 응급실에 실려간 환자의 가 족은 자신들이 기다리지 않기를 희망한다거나(the family member would hope that they don't have to wait in line to get treated and hope that the family member would be ok), 의사들은 심각한 문제를 환자 가족들에게 직접 이 야기해서는 안된다거나(we shouldn't say anything serious matter to family members directly), 이와 반대로, 기다리 는 환자에게 그들의 상황을 지속적으로 알려주어야 한다거 나(keep waiting patients constantly informed of their status), 환자를 위해 최대한 많은 해결책을 제시하여 가족 들의 불만이 나오지 않도록 노력해야 한다고 주장했다(offer many solutions for the rest of the family or person with particular patient and find solutions and give the family options to eliminate any chance of complaints). 따라서, 응급실 환자의 경험을 직접적으로 개선하기 위해서는, 환자 가족이 다른 병원으로 간다거나(find another hospital, if there's a line up), 의사가 차분하고 이성적으로 문제를 해 결해야 한다거나(the best solution would be to approach problem with calm and rational manner if possible), 또는 병원 측에서, 환자가 의사를 만나기 전에 일어나는 프로세스 를 줄여야 한다고 주장했다(to cut some of the process before seeing the doctor / they should try to shorten the process of each process and reduce the steps).

결론적으로, 두 그룹이 발견한 문제들과 해결책의 차이는 가설에서 제시된 것과 동일했다. 즉, 비공감 그룹은 환자 가족이 겪는 경험에 대한 구조적 형태의 개념적 지식정보 (Structured conceptual knowledge)를 더욱 많이 설명함으 로써 개념적 지식에 기반한 해결책을 제시했고, 공감 그룹은 경험에 대한 순차적 형태의 디자인 지식정보(Procedural design knowledge)를 더욱 많이 설명하며 디자인 지식에 기반한 해결책을 제시했다.

\section{General Discussion}

본 연구에서는, 서비스디자인의 사용자 조사 과정에서 발 생하는 두 가지 지식정보의 존재를 확인하였다. 아울러, 서 비스디자인에서의 사용자 경험 개선을 위해서 일반적으로 행해지는 사용자 조사방법에 관한 이론적 연구와 실제적 방 법을 제시하였다. 심리학 연구에 따르면 사용자 경험은 사용 자 본인이나 사용자 조사자가 설명하지 못하는 경향이 있으 며, 이를 극복하기 위하여 공감을 제시하였다. 응급실 환자 의 가족이 겪는 경험을 개선하기 위한 실험을 실행하여, 공 감 기법이 사용자 경험을 구조적, 개념적 판단보다 순차적, 구체적으로 이해한다는 점을 도출함으로써, 공감 기법이 서 비스디자인의 사용자 조사방법에 도움을 줄 수 있음을 실험 적으로 증명했다.

결론적으로 본 연구는, 서비스디자인의 사용자 조사단계에 서 발생하는 문제점을 이론적으로 설명하고, 이를 극복하는 하나의 대안을 제시함으로써, 서비스디자인의 학술적 지식기 반 연구의 시도가 가능함을 보여주었다.

\section{Acknowledgements}

This work was supported by the new faculty research program 2011 of Kookmin University in Korea.

\section{References}

Chesbrough, H. and Spohrer, J., "A Research Manifesto for Service Science", Communications of the ACM, 49(7), 35-40, 2006.

Cook, David, Goh, Chon-Huat. and Chung, Chen., "Service Typologies: A 
State of the Art Survey", Production and Operations management, 8(3), 318-338, 1999

Davis, Mark H., Laura Conklin, Amy Smith. and Carol Luce., "Effect of Perspective Taking on the Cognitive Representation of Persons: A Merging of Self and Other," Journal of Personality and Social Psychology, 70(4), 713-726, 1996.

Galinsky, Adam D. and Gordon B. Moskowitz., "Perspective-Taking: Decreasing Stereotype Expression, Stereotype Accessibility, and In-Group Favoritism," Journal of Personality and Social Psychology, 78(4), 708-724, 2000.

Gehlert, Andreas., Braun, Robert. and Esswein, Werner., "Temporal Aspects in Business Processes - An application to E-Government", Proceedings of EMISA. 2004, 234-245, 2004.

Gilbert, Daniel T. and Patrick S. Malone., "The Correspondence Bias," Psychological Bulletin, 117(1), 21-38, 1995.

Griffin, Abbie. and John Hauser., "The Voice of the Customer," Marketing Science, 12(Winter), 1-27, 1993.

Hempe, E., "Knowledge Flows in Service Design - A Framework", Proceedings of System Sciences(HICSS) $201144^{\text {th }}$ Hawaii International Conference, 1-10, 2001.

IfM and IBM., "Succeeding through service innovation: A service perspective for education, research, business and Government", Cambridge, United Kingdom: University of Cambridge Institute for Manufacturing, 2008.

Kahneman, D., Objective Happiness. In Kahneman, D., Diener, E. and Schwarz, N.(eds.). Well-Being: The Foundations of Hedonic Psychology. New York: Russel Sage. pp. 3-25, 1999.

Kruger, Justin. and Matt Evans., "If You Don't Want to be Late, Enumerate: Unpacking Reduces the Planning Fallacy," Journal of Experimental Social Psychology, 40(5), 586-598, 2004.

Patricio, Lia., Fisk, Raymond. and Falcao e Cunha, Joao., "Designing Multi-Interface Service Experiences", Journal of Service Research, 10(4), 318-334, 2008.

Regan, D. and Totten, J., "Empathy and Attribution: Turning Observers into Actors", Journal of Personality and Social Psychology, 32(5), 850-856, 1975.

Sako, Mari., McKenna, Chris., Molloy, Eamonn. and Ventresca, Marc., "Grand Challenges in Services", Proceedings of the GCS workshop, Said Business School, University of Oxford, 2006.

Sangiorgi, Daniela., "Building Up A Framework for Service Design Research", $8^{\text {th }}$ European Academy of Design Conference, 1-3 April 2009, The Robert Gordon University, Aberdeen, Scotland, 2009.
Smith, Ruth Ann. and Michael J. Houston., "A Psychometric Assessment of Measures of Scripts in Consumer Memory," Journal of Consumer Research, 12(2), 214-224, 1985.

Shostack, L. G., "Design Services that Deliver." Harvard Business Review, (84115): 133-139, 1984.

Storms M. D., "Videotape and the Attribution Process: Reversing Actors' and Observers' Point of View", Journal of Personality and Social Psychology, 27(3), 165-175, 1973.

Turner, Phil. and Turner, Susan., "Is stereotyping inevitable when designing with personas?" Design Studies 32, 30-44, 2011.

\section{Author listings}

Jaewoo Joo: jaewoo_joo@kookmin.ac.kr

Highest degree: $\mathrm{PhD}$ in Marketing, Rotman School of Management, University of Toronto

Position title: Assistant Professor of Marketing, College of Business Administration, Kookmin University

Areas of interest: Psychology of Judgment and Decision Making, Consumer Behavior, New Product Development, Design Management

Dongwoo Oh: dongwoo@id.iit.edu

Highest degree: $\mathrm{Ph}$. D. Candidate, Institute of Design, Illinois Institute of Technology

Position title: Researcher, Institute of Design, Illinois Institute of Technology

Areas of interest: Human-Centered System Integration, Service Design, User Experience Design, Interaction Design, HCI

Date Received : 2011-12-31

Date Revised :2012-01-16

Date Accepted : 2012-01-17 